\title{
Creating Quality Undergraduate Research Programs in Economics: \\ How, when, where (and why)
}

December 19, 2010

\author{
Stephen B. DeLoach \\ Professor of Economics \\ Elon University \\ Elon, NC 27244 \\ deloach@elon.edu
}

Elizabeth Perry-Sizemore

Associate Professor of Economics

Assistant Dean of the College

Randolph College

Lynchburg, VA 24503-1526

epsizemore@randolphcollege.edu

\author{
Mary O. Borg \\ Professor of Political Economy
}

Director, Undergraduate Academic Enrichment Program

University of North Florida

Jacksonville, FL 32224

mborg@unf.edu 


\begin{abstract}
While undergraduate research has been a growing movement across the academy for decades, economics has been relatively slow to embrace its importance. In this paper we argue for the development of comprehensive undergraduate research programs that not only require capstone research learning experiences, but that integrate the development of foundational research skills throughout the curriculum. We make four recommendations to departments that wish to either start an undergraduate research program or improve an existing one. One, departments should integrate Hansen's proficiencies into lower-level courses so that students learn foundational research skills. Two, departments should explore the feasibility of creating a laboratory environment in the economics department. While this may not be feasible for all department members, there are ways in which even non-experimental economists can build this type of research culture. Three, departments should require a research methods course. Four, all departments should consider making a research experience a required part of the senior capstone.
\end{abstract}

\title{
JEL Code: A2
}




\section{Introduction}

Undergraduate research is a growing movement in higher education. It is embraced at all types of institutions and on the rise across the humanities, social sciences, and sciences. But while it has been virtually omnipresent the sciences for decades, undergraduate research in economics is still in its infancy. A recent survey by McGoldrick (2008a) indicates that only a small fraction of economics departments consider doing undergraduate research to be an important goal for their undergraduate program.

While the case for undergraduate research has been articulated in other disciplines, economists have only recently started to argue for investing time and energy doing undergraduate research in economics (Borg and Perry 2007). To date, however, most of the papers in the economic education literature have focused exclusively on promoting different types of research activities. McGoldrick and Ziegert (2002), Brooks and Schramm (2007) and Ziegert and McGoldrick (2008) describe various service-learning projects. More recently, McGoldrick (2008) describes a course-based senior seminar approach based on Greenlaw’s (2006) seminal text.

This paper builds on the work of Borg and Perry (2007) and our work on the undergraduate research module of the web portal Starting Point: Teaching and Learning Economics (Science Education Resource Center 2010). ${ }^{1}$ Casual empiricism suggests that most economists are hesitant to get involved in undergraduate research because they do not know when to get students involved or where it is most appropriate to incorporate it into the curricula. It is one thing to know that a research-based service-learning project is considered undergraduate research, but it is another to know where and when it is going to work best and how it may build important skills that lead to further undergraduate research experiences. Another common problem is that often a single professor within a department decides he or she wants to do 
undergraduate research. However, we believe that quality undergraduate research requires more than good mentoring by passionate faculty member. It requires a department committed to the kinds of curricular development that provides students with the opportunity to build the foundational skills in their earlier years. That is why we believe this paper and the related Starting Point module have the potential for significant impact across the economics discipline.

Specifically, we develop a taxonomy of the various ways in which undergraduate economics majors can engage in meaningful research that develops key critical thinking skills. These include: (1) course-based activities (e.g., shorter quantitative writing assignments, naturalistic observation, etc.); (2) course-based projects (e.g., semester-long service learning projects, term papers in econometrics, etc.); (3) capstone experiences (e.g., honors theses, senior seminar papers); and (4) collaborative research with faculty. These forms may involve the analysis of archival data or engage students in collecting their own data. The existence of multiple forms of undergraduate research is ultimately suggestive of a hierarchy based on knowledge, complexity and independence.

This paper will do far more than simply describe alternative forms of undergraduate research. The ultimate purpose is to argue for the creation of a developmental model of undergraduate research that will guide the creation of new programs and improvement of existing ones. This includes the articulation of appropriate learning goals at each level of undergraduate research. These include theoretical and methodological content, critical thinking, and research skills. While some of these skills may be discipline-specific, much of it is generalizable. Ultimately, this research should lay the groundwork both for programmatic development as well as for future scholarship. For example, one underdeveloped area in the existing literature on undergraduate research, particularly that pertaining to economics, is 
measurable assessment. Before meaningful empirical assessment can be done, however, theory has to develop the testable hypotheses. In this regard, we see this project as seminal in the education economics literature.

\section{Why do Undergraduate Research?}

The Council for Undergraduate Research (CUR) defines undergraduate research to be any "inquiry or investigation conducted by an undergraduate student that makes an original intellectual or creative contribution to the discipline." Kinkead (2003) writes that "another hallmark of undergraduate research is the role of the mentor faculty member who guides the novice researcher and initiates the student into the discipline" (p. 6). In 2005, the National Conferences on Undergraduate Research (NCUR) and CUR (now merged) issued a joint statement that undergraduate research is a four-step learning process that involves:

1. the identification of and acquisition of a disciplinary or interdisciplinary methodology

2. the setting out of a concrete investigative problem

3. the carrying out of the actual project

4. finally, the dispersing/sharing of a new scholar's discoveries with his or her peers- a step traditionally missing in most undergraduate educational programs. (CUR and NCUR 2005)

Essentially, undergraduate research involves the same steps as research done by professionals. A word of caution is warranted at this point. The above definition of undergraduate research is rather restrictive. It requires that students to be engaged in all of these four steps of the process. Since the purpose of this paper is to argue for the holistic development of undergraduate research programs, we place more emphasis on the importance of providing students with experiences that develop fundamental research skills than on requiring that students complete all steps in the research process for each project. Ideally, however, students will have the opportunity at some point to engage in a higher-level experience that meets this 
definition. Thus along with more traditional experiences like capstone or collaborative research, we discuss a number of course-based activities and projects that we argue fall under the more inclusive umbrella of undergraduate research experiences since they serve to develop the requisite skills that provide the foundation for deeper, more sophisticated undergraduate research later in their major.

The benefits of undergraduate research are as wide-ranging as the forms and levels of intensity that it can take. The undergraduate research module at the online Starting Point: Teaching and Learning Economics identifies these benefits and describes the results of studies of the student learning outcomes of undergraduate research experiences in a variety of disciplines. Undergraduate research helps students learn about both a particular topic in a field and the research process in general. It is inquiry-based learning that involves practicing a discipline and not just being told about it, and as such helps students learn both content and practical skills. As a form of engaged learning, it helps students understand the contexts for knowledge, can foster self-confidence and ownership of learning, and can enhance metacognition, or understanding of one's own learning. It promotes the cognitive development of students by developing expert learners, individuals who understand how a discipline is organized and can use that structure to ask and answer questions. And it promotes students' affective development as well, as it requires them to grapple with the unknown and make informed judgments about the answers to questions when there may be no one unambiguous answer. Some forms of undergraduate research also support faculty research and benefit colleges and their communities (Starting Point, 2010.)

In economics, a number of these benefits of undergraduate research are directly related to specific learning objectives that have long been advocated for the major. Economic educators 
Salemi and Siegfried (1999) support active learning for the undergraduate economics curriculum and stress the importance of using Hansen's proficiencies as the basis for defining learning objectives in and across courses in the major. A Hansen's proficiencies approach to the major is one structured to promote student skills in the following cognitive areas:

- Accessing existing knowledge

-Displaying command of existing knowledge

- Interpreting existing knowledge

- Interpreting and manipulating economic data

- Applying existing knowledge

- Asking pertinent and penetrating questions

- Creating new knowledge (List reproduced from Hansen, 2006.)

Undergraduate research is a form of active learning that can develop a number of these proficiencies. In fact, by engaging students in doing economics, undergraduate research can help students better understand the value of what they learn in the major by showing the relationship of these proficiencies to one another. McGoldrick (2007) even shows that Hansen's proficiencies can be mapped directly to the research process (see Table 1).

In a survey of undergraduate majors, Hansen (2001) found that the average student rates herself between basic and proficient on the low- and mid-level proficiencies and very low on the highest proficiencies, suggesting that students are falling short of both understanding and experiencing the research process (p. 234). Undergraduate research experiences may help students achieve these higher-level proficiencies and develop more practice and comfort with the lower-level ones. 
Table 1: Undergraduate Research and Hansen's Proficiencies (McGoldrick 2007)

Key Steps in the

Undergraduate

Research Model

1. Identifying

economic issues

2. Developing a

research question

3. Undertaking a

literature search

4. Summarizing relevant literature

4. Summarizing relevant literature

5. Identifying an area of potential

contribution

6. Locating and analyzing data

7. Drawing conclusions

8. Comparing conclusions to identified literature 9. Applying analysis to current policy issue

10. Presenting research to peers and/or faculty
Hansen's Proficiencies for the Economics Major

Accessing existing knowledge: Locate published research in economics and related fields; locate information on particular topics and issues in economics; search out economic data as well as information about the meaning of data and how they are derived.

Asking pertinent and penetrating questions. Demonstrate an understanding of questions that stimulate productive discussion (factual, interpretative and evaluative) and that reflect particular concerns when engaged in discussing economic issues and policies.

Displaying command of existing knowledge: Write a precis of a published journal article; summarize in a two-minute monologue or a 300-word written statement what is known about the current condition of the economy; summarize the principal ideas of an eminent economist; summarize a current controversy in the economics literature; state succinctly the dimensions of a current economic policy issue; explain key economic concepts and describe how they can be used.

Interpreting existing knowledge: Explain what economic concepts and principles are used in economic analyses published in articles from daily newspapers and weekly news magazines; read and interpret a theoretical analysis, which includes simple mathematical derivations, reported in an economics journal article.

Interpreting and manipulating economic data: Construct tables from already available data; explain how to understand and interpret numerical data found in published tables such as those in the Economic Report of the President; be able to identify patterns and trends in published data such as those contained in the Digest of Educational Statistics; read and interpret a quantitative analysis, including regression results, reported in an economics journal article.

Applying existing knowledge: Prepare a five-page written analysis of a current economic problem; prepare a two-page decision memorandum for a superior that recommends some action on an economic decision faced by the organization; write an op-ed essay on some local economic issue.

Creating new knowledge: Identify and formulate a question or series of questions about some economic issue that will facilitate its investigation; prepare a five-page proposal for a research project; complete a research study with its results contained in a carefully edited 20-page paper. 
Siegfried et al (1991) identify economics as a way of knowing. Undergraduate research helps students learn how knowledge is constructed in a discipline by offering them firsthand experience with the process. Undergraduate research in economics therefore teaches economics in its truest sense, as something far more than a set of facts and concepts. The opportunity to discover this need not be restricted to students bound for graduate school, and the following section of this paper suggests a wide variety of entry points and ways for students to experience undergraduate research in economics. Hansen's proficiencies can be used to identify and construct appropriate learning objectives that can inform the design and intensity of the undergraduate research experience.

\section{Undergraduate Research Experiences}

The common feature in any undergraduate research experience is that students must engage in the process of creating and disseminating knowledge. While far from universal within undergraduate economics programs, a 2005 survey finds writing experiences that stress aspects of research methods are considerably more common than they were just 15 years ago (McGoldrick 2008a). There are a number of different approaches currently used to teach these research skills. McGoldrick (2008a) finds that 60 percent of economics departments in the United States require some sort of capstone experience. Most of these are capstone courses (49 percent). Only 16 percent of departments require a senior thesis for all economics majors. But not all of these even emphasize making an "original contribution" as one of their learning goals, as only 36 percent of those departments with a capstone experience consider "making an original contribution" to be an important goal in their program.

While undergraduate thesis and some capstone experiences easily satisfy this definition of undergraduate research, earlier opportunities that emphasize collaboration and original 
contribution may also meet this criterion. More importantly, these earlier experiences are likely to improve the quality of subsequent experiences by developing the requisite skills and methodological knowledge. In general, undergraduate research experiences in economics can take one any one of four basic forms:

Course-based activities like naturalistic observation, surveys, quantitative writing assignments, and experiments can often be structured to walk students through a subset of the steps of the research process.

Course-based projects like term papers, service learning, and community-based and campus-based learning can be of a research nature.

Capstone experiences like senior research projects and honors research experiences can allow students to develop and explore a research question of their own.

Student-faculty collaborative research like summer research experiences provide opportunities for students to work alongside a faculty member on his or her own ongoing research or on a project designed by both.

Recall that we have argued previously that for the purposes of curricular development, it is not productive to quibble over strict definitions of undergraduate research. According to CUR, only the latter two of these categories (capstone and collaborative experiences) could meet the strict definition of undergraduate research. In fact, even some capstone or collaborative research projects would not meet all 10 of the research steps outlined by McGoldrick (2007) (given in Table 1). In particular, step 2, developing a research question, and step 5, identifying the area of potential contribution, are often determined by the professor. This is almost certainly the case in collaborative projects, but may also be true of capstone seminar papers that are thematic in nature. Nevertheless, since all these activities and projects develop foundational research skills, we believe that it is important that a discussion of their role and form be included here. 
These forms can be differentiated on the basis of five criteria. These include length of experience, intensity of activity, degree of student control over the research process (level of decision-making), pre-existing student content knowledge (i.e., level of course), and the extent of

faculty collaboration and mentoring. ${ }^{2}$ Of course, all of these dimensions are ultimately driven by the learning goals and objectives. These distinctions are summarized in Table 2 and discussed in detail below.

\section{III.A. Course-Based Activities}

Course-based activities are perhaps the most controversial and least conventional of all of these forms. Because of the short length of time and the focus of the activities, many would simply categorize them as active learning, but not true undergraduate research. We, however, prefer to adopt the broadest, most inclusive point of view. As long as the objectives of the project provide the opportunity for students to make an intellectual contribution to disciplinary knowledge, such activities should be considered undergraduate research. If the potential exists to discover something new, it should be considered. This contrasts with activities where students are asked merely to replicate another's results. While a good learning exercise, it is not research since the objective is limited to the students' discovery of pre-existing knowledge. 
Table 2: Taxonomy of Undergraduate Research

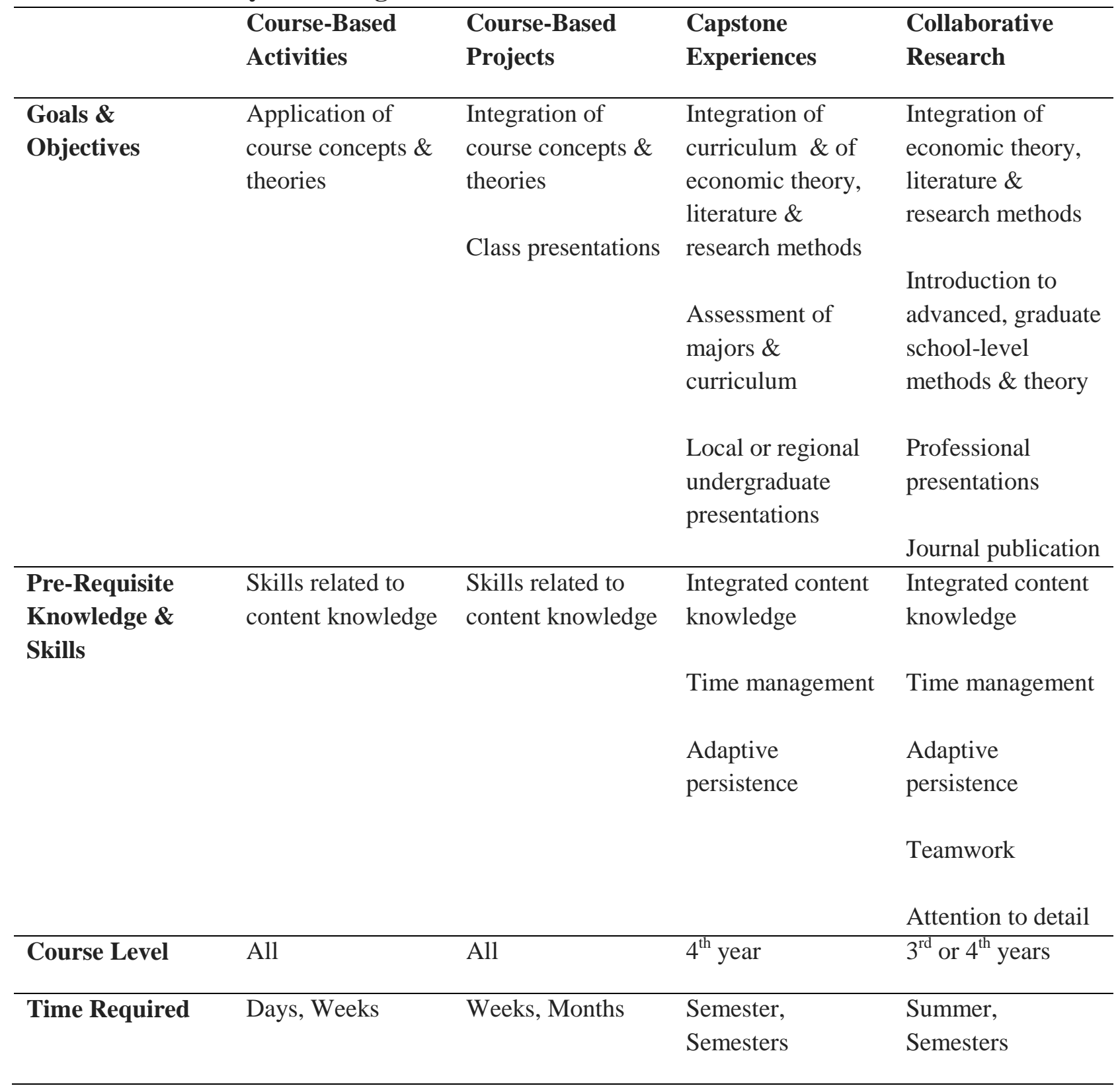


Table 2 continued

\begin{tabular}{|c|c|c|c|c|}
\hline \multirow{4}{*}{$\begin{array}{l}\text { Project Intensity } \\
\text { \& Degree of } \\
\text { Student } \\
\text { Responsibility }\end{array}$} & Highly structured & Structured & Unstructured & Varied structure \\
\hline & $\begin{array}{l}\text { Question typically } \\
\text { common to all } \\
\text { students in the } \\
\text { class }\end{array}$ & $\begin{array}{l}\text { Students } \\
\text { responsible for } \\
\text { limited number of } \\
\text { research decisions }\end{array}$ & $\begin{array}{l}\text { Students } \\
\text { responsible for } \\
\text { almost all research } \\
\text { decisions }\end{array}$ & $\begin{array}{l}\text { Students } \\
\text { responsible for } \\
\text { limited number of } \\
\text { research decisions }\end{array}$ \\
\hline & $\begin{array}{l}\text { Students make few } \\
\text { research decisions } \\
\text { Project covers few } \\
\text { of steps in research }\end{array}$ & $\begin{array}{l}\text { Project covers } \\
\text { more, but not all, } \\
\text { of the steps in } \\
\text { research process }\end{array}$ & $\begin{array}{l}\text { Project covers } \\
\text { most if not all } \\
\text { steps of the } \\
\text { research process }\end{array}$ & $\begin{array}{l}\text { Project covers all } \\
\text { steps of the } \\
\text { research process }\end{array}$ \\
\hline & $\begin{array}{l}\text { process outlined in } \\
\text { Table } 1\end{array}$ & & & $\begin{array}{l}\text { High degree of } \\
\text { oversight from } \\
\text { faculty }\end{array}$ \\
\hline \multirow[t]{6}{*}{ Mentoring Focus } & $\begin{array}{l}\text { Individualized or } \\
\text { Group }\end{array}$ & $\begin{array}{l}\text { Individualized or } \\
\text { Group }\end{array}$ & Individualized & Individualized \\
\hline & $\begin{array}{l}\text { Simple problem- } \\
\text { solving-based } \\
\text { mentoring }\end{array}$ & $\begin{array}{l}\text { Individualized } \\
\text { mentoring }\end{array}$ & $\begin{array}{l}\text { More personal, } \\
\text { professional } \\
\text { development }\end{array}$ & $\begin{array}{l}\text { Most personal and } \\
\text { professional } \\
\text { development }\end{array}$ \\
\hline & $\begin{array}{l}\text { More teaching } \\
\text { than mentoring }\end{array}$ & $\begin{array}{l}\text { Complex problem- } \\
\text { solving-based } \\
\text { mentoring }\end{array}$ & $\begin{array}{l}\text { High-level } \\
\text { problem-solving, } \\
\text { roadblocks, ill- }\end{array}$ & $\begin{array}{l}\text { Socialization into } \\
\text { the profession }\end{array}$ \\
\hline & & $\begin{array}{l}\text { Limited personal, } \\
\text { professional }\end{array}$ & $\begin{array}{l}\text { structured } \\
\text { problems }\end{array}$ & $\begin{array}{l}\text { Emotional ups and } \\
\text { downs of research }\end{array}$ \\
\hline & & development & $\begin{array}{l}\text { Maintaining focus } \\
\text { and forward } \\
\text { momentum }\end{array}$ & $\begin{array}{l}\text { Strong emphasis } \\
\text { on professional } \\
\text { writing }\end{array}$ \\
\hline & & & $\begin{array}{l}\text { Some emphasis on } \\
\text { professional } \\
\text { writing }\end{array}$ & \\
\hline
\end{tabular}

The key characteristic of course-based activities that distinguishes them from other forms is the scope and length of the activity. Student responsibility for all steps in the research process is not feasible in such activities. To deal with the time constraints, instructors have to take away many (if not most) of the key research decisions from the students. For example, the instructor 
might determine the broad research question (steps 2 and 5 in Table 1) for the class rather than requiring students to find their own topics. In this kind of assignment, students are still free to create their own theories to answer the question and often make individual decisions pertaining to data and testing. While they may be following most of the steps of the research process detailed in Table 1, many of those (e.g., step 6: locating and analyzing data) may be done at a simplistic or superficial level depending on the level and goals of the course.

Some examples of these kinds of projects include those described by Greenlaw and DeLoach (2003) in the context of using electronic discussions in class. For example, in their "Productivity Slowdown" discussion, students explore competing theories about one of the most complex, controversial debates in macroeconomics over the past 30 years. Economists have developed dozens of theories to account for this, but no consensus has been reached. In this example, students discover the existing theories, but are asked to collect data and perform their own analysis to "test" the alternative hypotheses and present their conclusions in some kind of written form. While their analysis is obviously less sophisticated than that of professional economists, the fact that they are doing independent analysis in and of itself means it should be considered as a form of undergraduate research.

Another example that fits this classification is course-based experiments, especially in an experimental economics course. While students may be using a published experimental design, they are not simply replicating existing results since they are, by definition, generating new data. As a result, it is a valuable research experience that gives students practice performing (at least) steps 6 and 7 of the research process. Of course, such experiments might also be part of a larger term paper. In that case, potentially all 10 of the steps could be touched upon (see the following section on course-based projects) Note, however, experiments run by the instructor to engage 
students in an active learning exercise merely to illustrate some basic economic concepts do not meet the definition of research. In those cases, the students are more "subjects" than they are researchers. But when students recruit subjects and run their own protocol for the purpose of testing theory, it is clearly research.

\section{III.B. Course-Based Projects}

The main difference between course-based activities and course-based projects lies in the length and purpose. Activities are shorter in length and the learning objectives tend to relate to a subset of content from the course. The level of student responsibility (i.e., number of steps of the research process under the control of the student) is also far more limited. Projects, however, are meant to be more summative. These require students to integrate most (if not all) of the content from the course into a cohesive research project. The classic example of this is the econometrics research paper. Most schools incorporate such an assignment into their undergraduate econometrics course. ${ }^{3}$ Students may be asked to formulate their own question, collect their own data from secondary sources and perform the appropriate econometric analysis to answer their research question. In this sense, all 10 steps (and all 7 of Hansen's proficiencies) are touched upon. However, due to time constraints the steps are obviously done with varying degrees of sophistication. As DeLoach (2010a) notes, such papers necessarily must focus on the econometric content over the theory and literature. While many will require that some journal sources are used as part of a "literature review" for the paper, it is clear that the preponderance of the student's time (and grade) will focus on the extent to which they test for, and address, the econometric issues that their data pose. 
Obviously course-based research projects are not limited to econometrics courses. Research projects in applied field courses also fall into this category, as do some independent research projects that students do at lower levels. ${ }^{45}$ Like econometrics papers, these also tend to require that students formulate their own research question and topic. However, like the econometrics projects discussed above, these typically do not require students to fully experience all the steps of the research process like longer experiences can. Often, these papers are theoretical in nature, leaving econometric testing for another time (thus skipping steps 6-10 of the research process). For example, students might be required to do a full literature review, explain the theory, and propose a research methodology to test the theory. ${ }^{6}$

One of the more unique examples of course-based projects that may meet the definition of research is service-learning projects (Brooks and Schramm 2007). As with many other course-based projects, the instructor determines the focus for the project (steps 2 and 5 of the research process). Unlike typical course projects, however, students in service-learning projects are more likely to work in teams and the focus of their research is more likely to be applied (versus basic research) in nature. One example of this kind of experience is so-called community-based research. Brooks and Schramm (2007) describe an economic impact project to examine the impact of the University of Vermont on its regional economy. This project involved a four-course sequence overseen by a 14 member advisory board that set the research agenda and ultimately would be responsible for implementing recommendations based on the research. Two other examples come from Perry-Sizemore (2010a, 2010b). In each of these examples, she discusses the need to first familiarize students with the organizations and community they will be ultimately serving with their research. In this way, the research differs 
significantly from most research projects. A final presentation to the relevant community (vs. a merely academic audience) is made based on the research findings.

\section{C. Capstone Experiences}

Unlike course-based activities and projects, capstone experiences are more likely to be designed so that students are responsible for all the steps in the research process. This is confirmed by McGoldrick's (2008a) survey results. The vast majority of these experiences require students to develop a research question, complete a review of the literature, collect and analyze data, draw conclusions, and make a formal presentation. The goal of a capstone research experience is to integrate knowledge from most (if not all) the student's economics courses. In

this sense, these experiences appear the most recognizable to those of us who do "real research." Because of the increased length of time and depth of knowledge, they also are more likely to allow for the creation of new knowledge (step 5 in Table 1). However, as McGoldrick (2008a) found, in most departments the ability to make an original contribution to the field is not a primary goal for most of these projects.

Within the set of capstone and thesis experiences that do include the making an original contribution as a learning goal, the length and structure varies widely. The shortest of these is the one-semester capstone experience (McGoldrick 2008b), while honors theses often last nearly two years (Siegfried 2001). Of course, there are a variety of experiences that fall somewhere between these in length. Borg (2010a) describes a project appropriate for a one-semester capstone research course. Lilly and Tiemann (2008) and DeLoach (2010b) describe a twosemester senior thesis process that begins with a 2-hour preparation course in the first semester and culminates with a 2-hour independent research project in the second semester. The big 
difference between one-semester experiences and longer ones lies in the depth of student experience and the type of mentoring possible (and expected).

For the most part, these experiences mimic the level of mentoring one expects (or hopes) to see in graduate school. In addition to the extended time, thesis students are usually expected to do significantly more literature review than their one-semester counterparts. Many are also expected to learn theories and apply methods well beyond what is covered in the standard curriculum. In this sense, students are not only to integrate and synthesize what they have learned in their major, but to develop the skills to learn independently. But unlike graduate students, undergraduates require considerably more hands-on mentoring. Siegfried (2001) suggests setting short-term deadlines to keep honors students on task (also see Borg 2010b). DeLoach (2010c) takes this a bit further, suggesting semester contracts over the course of a three-semester-long honors thesis.

\section{D. Collaborative Research}

Many colleges also offer students the ability to collaborate with faculty on a joint project. Often such projects start in the summer. The big difference here is that these experiences are more likely to follow an apprenticeship model. Most often, a professor has invited top students to work on a project that is part of the faculty's research agenda. For a number of reasons, these experiences offer students a taste of graduate school is like. Faculty often think of this as a way to introduce gifted students to the profession. Because of this, the ultimate goals are quite different than other types of research undergraduates typically do. In fact, since it is collaborative students are likely to have even less responsibility for the different steps in the research process than they would in capstone experiences. While students may experience less 
breadth, they probably do get considerably more depth in these collaborative experiences. The product of these projects typically is a new working paper that will be presented at professional conferences and (hopefully) published in a peer-reviewed journal. ${ }^{7}$ However, this is not necessarily the case. Many professors choose to treat these projects more like deeper versions of capstone or course-based projects. These could range from community-based projects (e.g., economic impact studies) to student-driven research ideas. Institutional incentives can affect the design and intensity of these experiences since often these projects are part of the larger community outreach with which departments and colleges may be involved.

\section{III.E. Summary}

The various activities discussed above differ considerably and some would argue with our classification of some activities as "undergraduate research." Whether course-based activities should be considered research or not does not diminish their importance in the developmental process. These activities lay the foundation for later, successful, undergraduate research projects.

Fundamentally, there is a logical hierarchy whereby students learn basic research skills in lower-level courses, develop their ability to integrate content knowledge and research skills in upper-level courses, and ultimately pull it all together in either independent or collaborative research projects in their later semesters. The creation of successful undergraduate research programs depends critically on both understanding this developmental model and securing the necessary resources to support it. These issues are discussed in the following section. 


\section{Implications for Programmatic Development}

The developmental model of undergraduate research examined above has a number of implications for programmatic development. But there is no one-size-fits-all solution to these challenges. Much depends on the institutional culture and its constraints, as well as on the department's design of the economics major itself. For example, many economics departments have such a large service load, either to a business program or to general studies, that they have few degrees of freedom when it comes to developing new classes for the major. Rather than detailing what we believe to be the optimal program to support the development of a strong undergraduate research program in economics, we have chosen to discuss several possible options for departments to consider. Many of them require a departmental "buy in" in that course goals need to be reconsidered, and in some cases, curriculum changes are required. Others require institutional support (see Section V.). Even in the absence of either the optimal departmental curriculum or institutional support mechanisms, we believe these recommendations offer guidance to faculty in their efforts to begin building their undergraduate research program.

\section{Recommendation 1: Integrate Hansen's Proficiencies in Lower-Level Courses}

Whether or not the curriculum contains a stand-alone research methods course, it is critical that students have the opportunity to develop foundational skills early on. Many of the skills needed to do quality research can be more generally thought of as critical thinking skills. Most of these are already learning goals in most lower-level courses. However, one key area that is often over-looked is the connection between theory and empirical evaluation. Even if students have not had a statistics or research methods course, students can still be asked to look to data to verify theoretical predictions, even if it is merely in a casual, descriptive way. Examples of such assignments include Greenlaw (2010) and Gregory (2010). 
More generally, acknowledging the relationship between Hansen's proficiencies and the steps of the research process as described in Table 1, we can examine lower level courses to determine whether, where, and to what extent each of Hansen's proficiencies are addressed in the major. This can help us assess the degree to which we are providing the scaffolding necessary for a research-focused capstone that integrates these skills. As we have shown, lower-level undergraduate research experiences like course-based activities and projects should be considered in the set of pedagogical practices that can be used to address these proficiencies. One of the benefits to choosing these types of activities is that they may help students recognize the relationships of the skills they are building to one another, to the scientific method, and to the process of doing economics.

\section{Recommendation 2: Build a Laboratory Team}

Developing an on-going research program for undergraduate students requires a multistep strategy that begins as early as the first year that a student enters college. For this purpose it is useful to borrow the laboratory framework that is used in the natural sciences. Our faculty colleagues in the sciences often bring promising students into their labs as first or second year students. The students usually begin with simple tasks in the lab but gradually move on to more advanced tasks as their skills and knowledge increase. Of course, even the most motivated student may not be willing to do this work over a long period of time without getting some small amount of academic credit for their efforts. These and other related issues are addressed in Section V.

Faculty members in the social sciences can set up a regular meeting time each week for students to meet with them to work on their research. This weekly meeting is the economist's 
equivalent of laboratory time. Students can be divided into teams to work on various research studies or to work on different aspects of the same study. New members of the team, i.e., the first or second year students, can begin with data searches, data entry, and literature searches. As students advance in experience and knowledge, they can take on more sophisticated tasks such as literature reviews and basic data analysis. By the time students are juniors and seniors, they should be able to pose their own research questions and design their own studies. ${ }^{8}$ At that point, they will be able to write their honors theses in economics or co-author papers with their faculty mentors.

It is more challenging to apply this model in economics because most of our empirical research is not as labor-intensive as it is in fields in which "controlled experiments" dominate the methodology. However, it can be successfully adapted if faculty members are willing to put in the upfront time with their students. Once a successful cadre of student researchers is established, the research team can become self-sustaining with the older students doing most of the mentoring of the younger students.

One successful example of this strategy comes from a psychology colleague who has established a research team in his field of expertise - personality theory. He and the students on his team meet every Friday for two hours to work on their research. The younger students begin by helping him or the older students with their research, but within a year or two they are devising their own research studies based on their own interests. For example, one student may be studying the effect of personality type on prison recidivism rates, while another may be studying the effect of personality type on the longevity of romantic relationships. Often his students suggest applications of personality theory to areas he has never considered. Not only 
has his research team spawned a large number of students who go on to earn doctorates in psychology, but it has also significantly improved his research record.

How can economists establish these kinds of research teams with their own students? It begins by talking about one's own research agenda in the Principles of Economics class. This may be easier to do in smaller Principles or Honors sections where faculty have time to incorporate non-textbook readings, but it can be done in a large sections as well. The professor can ask students who are interested in learning more about economic research opportunities to come talk during his or her office hours. Those students can then be asked to take a special section of a research methods course that will serve as the dress rehearsal for membership on the research team.

\section{Recommendation 3: Create a Research Methods Course}

Perhaps one of the difficulties that economists face in helping our undergraduates do research is that standard research methods classes often put the cart before the horse. With some exceptions, most of these courses are taught as applied statistics courses with little time and attention given to the steps that come before the data analysis. If this is the case, students learn the technical steps to data analysis but not the more subtle steps of how to choose a research topic that interests them, how to put a research idea into a testable hypothesis, how to write a literature review that is more than an annotated bibliography, and how to find data for testing their hypotheses.

One reason for this is that many economics majors take a standard "business and economics statistics" course. Others may be required to take a general statistics course taught by 
the math or statistics department. In either case, we need to understand that our economics majors need to learn "research methods" and not merely "statistics."

For example, a research methods course that students take before they take statistics or econometrics could spend two-thirds of the semester dealing with those questions that come before a student is ready to run a regression analysis. ${ }^{9}$ The last third of the course would cover simple hypothesis testing, with students learning to perform t-tests, crosstabs, ANOVAs, and basic regression analysis. The final paper that is assigned can ask the students to specify a research project that they would like to undertake, but one that they don't actually have to complete. In this case, they still choose a topic, write a literature review that includes at least five articles from scholarly journals or books, specify a research thesis in the form of a testable hypothesis, discuss the data that exists for testing the hypothesis or write a survey questionnaire that could be used for collecting the data that they will need. Even if they are not actually completing the research, per se, students are still exposed to four of Hansen's proficiencies (1, 2, 3, and 5) even without doing any actual data analysis. A research methods course that comes after could be designed in a similar way to the example above. But since students presumably have pre-existing knowledge of basic statistics (including regression), there is no reason they could not complete the research project. In this case, students will have completed their first undergraduate research project (a course-based project).

For various reasons, all departments have unique constraints that will affect their ability to offer such experiences to students. What is important is not when research methods are taught, but that they are taught. Whether as a stand-alone course or in conjunction with another course (e.g., a required econometrics course), the earlier students develop these skills, the better. If this course is taught, or these skills are learned, prior to the senior year, then (1) the capstone 
experience can be more significant and (2) the most motivated students will have the opportunity to or do collaborative research with faculty either in the summer or during the year.

\section{Recommendation 4: Reconsider the Capstone}

Finally, recent research makes it clear that many economics departments should reconsider the goals of their senior capstone experiences. As McGoldrick (2008a) has found, few programs currently even consider the ability of undergraduates to make a contribution to the disciplinary knowledge to be a legitimate goal. This is at the heart of what it means to do undergraduate research. Little more than 1 in 5 departments are currently on board with such a

lofty goal. Forty percent of economics departments have no capstone requirement at all and only about one-third of those who do are emphasizing research in this way.

It is difficult to ascertain why so few of the existing capstone experiences do not require students to do research. Is it because they do not require statistics, econometrics or research methods? Or perhaps it is because the research methods course $i s$ the capstone? Or perhaps the capstone course is really simply one field course that all students are required to complete?

Whatever the reason, whatever the unique constraints, we believe that all capstone experiences can and should incorporate undergraduate research as one of their learning goals. Given the relatively inclusive categories of undergraduate research summarized in Table 2, there is no reason why all undergraduate economics majors cannot have some sort of undergraduate research experience before they graduate.

\section{Support for Undergraduate Research}


The recommendations discussed in the previous section do not come without a cost. Faculty and departments that choose to invest valuable time into such efforts need support, including time, rewards, money and development. There are two sources for this support: internal and external. In this section, we discuss some of the areas in which support is most needed and offer some existing resources for capitalizing on existing support structures.

\section{V.A. Institutional Support}

The amount of institutional support that colleges and universities give to undergraduate research runs the gamut from none to substantial, depending on the institution's mission and resources. At a minimum the institution needs to recognize the faculty effort that goes into establishing a sustained undergraduate research program when it comes to faculty evaluations for promotion, tenure, and merit pay. This means acknowledging contributions in this area when it comes time to evaluate faculty in the teaching category. Even more importantly, if a faculty member publishes a paper with a student, this should be celebrated, rather than counted against the faculty member because it is co-authored.

If students are given academic credit for the research, this should be acknowledged as well. Many universities use a banking system for faculty who supervise independent study courses with students. For example, they establish a given number of independent studies that is equivalent to one course so once a faculty member reaches that number, he or she will receive a one course reduction in teaching load for the next term. An even better arrangement would be to allow the faculty member to count his or her research team meeting as a course, though that may be more difficult in these budget-strapped times. The presence of binding budget constraints is 
another reason for departments to place increased emphasis on course-based activities and projects.

Public recognition for students and faculty who engage in research is another important form of institutional support. Many colleges and universities hold undergraduate research symposia that allow students to showcase their research accomplishments either through poster sessions or paper presentations. These can be defined as broadly or as narrowly as the university chooses. For example, a particular college or program may wish to hold its own symposium, or the symposium may be campus-wide and include creative projects as well as more traditionally defined research projects. Another form of public recognition comes by publishing a campus undergraduate research journal. To hold costs down, these journals can be published on the college or university's website. However the recognition is given, it is important for faculty and students to know that the institution appreciates their efforts.

Other forms of institutional support for undergraduate research require a larger financial commitment. For example many universities offer competitive grant programs that give financial support to both the faculty members and the students who engage in research together. Many colleges and universities provide summer research programs that pay students a stipend and offer them housing while they do research on campus over the summer. These programs are especially beneficial because both students and faculty can devote their entire attention to research during the summer months. Student travel grants that help pay for students to present their research at professional meetings are another useful financial benefit that many universities offer their undergraduate researchers. 


\section{B. External Support}

The Council on Undergraduate Research offers many resources and opportunities for students and faculty engaged in undergraduate research. In addition to offering institutional memberships, individual faculty members and college administrators can join CUR. As its webpage states, as part of its mission CUR works to support funding for collaborative research, disseminates best practices, and offers workshops for individuals and institutions seeking to further their commitment to undergraduate research (Council for Undergraduate Research). In addition, it operates an online graduate school registry where undergraduate researchers can provide details of their research activities and accomplishments to graduate programs and a list of journals and symposia that showcase undergraduate student research. Between institutional and individual memberships, over 900 colleges and universities are represented in CUR.

NCUR and CUR recently merged. For years, NCUR's signature accomplishment has been to sponsor an annual conference for students (National Conferences on Undergraduate Research). These conferences provide opportunities for students of all disciplines to network and to present original research to peers and faculty in discipline-specific sessions. NCUR also offers faculty development sessions focused on best practices in mentoring and collaboration in undergraduate research. Beyond experiencing the learning benefits of delivering original research and receiving oral feedback on it, by taking advantage of the opportunity to attend sessions in many disciplines, students (and faculty!) begin to understand and respect how the processes of intellectual inquiry compare across disciplines.

Specific to the economics profession, there are some first-rate examples of undergraduate research being showcased in national undergraduate journals such as the Undergraduate Economic Review published at Illinois Wesleyan University, the Michigan Journal of Economics 
at the University of Michigan-Ann Arbor, and Issues in Political Economy co-published by Elon University and the University of Mary Washington. In addition, some state and regional economics conferences hold sessions for undergraduate presenters.

Insofar as best practices are concerned, McGoldrick (2007) offers some specifically for economists. CUR publishes mostly non-discipline-specific literature (including Merkel's 2002 guide on how to mentor undergraduate researchers), and both CUR and NCUR offer opportunities for faculty engaged in undergraduate research to share pedagogical practices. The undergraduate research module at Starting Point: Teaching and Learning Economics is a new resource for economists who want more guidance on developing undergraduate research experiences. The module, one of 16 pedagogical modules on the site, provides resources and successful examples of undergraduate research in economics from campuses across the country.

An important source of external financial support for undergraduate research is provided through the National Science Foundation's Research Experience for Undergraduates (REU) Program. This grant program provides funding directly to universities that offer intensive summer research programs in a variety of academic disciplines. In addition to funding programs in the natural and biological sciences, the program also supports summer research in the social, behavioral and economic sciences. A university with a strong undergraduate research program may apply to host a site by applying for an REU grant. A university that receives a grant to host a site will receive the funds necessary to operate the program as well as the funds necessary to support the students, including room, board and a stipend. More importantly, students from any college or university can apply to participate in one of the summer REU program sites..$^{10}$ 


\section{Conclusions}

While undergraduate research is widely accepted and valued throughout the academy economics departments have been relatively slow to integrate it into their departmental goals and curricula. This is true even at smaller colleges and universities that embrace undergraduate education as their primary mission. In this paper we have argued for the holistic development of comprehensive undergraduate research programs that not only require capstone research learning experiences, but that integrate the development of foundational research skills throughout the curriculum.

In particular, we have made a handful of strong recommendations to departments that are considering starting an undergraduate research program or want to improve an existing one. One, departments should integrate Hansen's proficiencies into lower-level courses so that students learn foundational research skills. Two, departments should explore the feasibility of creating a laboratory environment in the economics department. While this may not be feasible for all department members, there are ways in which even non-experimental economists can build this type of research culture. Three, departments should require a research methods course. Four, all departments should consider making a research experience a required part of the senior capstone. 


\section{References}

Borg, M. and Perry, E. (2007). "Why, where and how undergraduate research matters to economics". Working paper, University of North Florida, Jacksonville, and Randolph College, Lynchburg, Virginia.

Borg, M. (2010a). "The Effect of Race and Ethnicity on High School Graduation Rates in Florida," in Starting Point: Teaching and Learning in Economics, [internet:http://serc.carleton.edu/econ/studentresearch/examples/36498.html].

Borg, M. (2010b). "Undergraduate Research Student Contract," in Starting Point: Teaching and Learning in Economics, [internet:

http://serc.carleton.edu/files/introgeo/studentresearch/examples/undergraduate_research_student. $\underline{\text { docx }}]$.

Brooks, N. and Schramm, R. (2007). "Integrating Economics Research, Education, and Service." Journal of Economic Education, 38, 3, 36-43.

Council on Undergraduate Research and the National Conference on Undergraduate Research (2005). "Joint Statement of Principles in Support of Undergraduate Research, Scholarship, and Creative Activities," [internet: http://www.ncur.org/ugresearch.htm]

DeLoach, S.B. (2010a). "Research Paper in Introductory Econometrics," in Starting Point: Teaching and Learning in Economics, [internet: http://serc.carleton.edu/dev/introgeo/studentresearch/examples/36319.html].

DeLoach, S.B. (2010b). "Economics Senior Thesis," in Starting Point: Teaching and Learning in Economics

[internet: http://serc.carleton.edu/dev/introgeo/studentresearch/examples/36324.html].

DeLoach, S.B. (2010c). “Three-Semester Honors Thesis,” in Starting Point: Teaching and Learning in Economics

[internet:http://serc.carleton.edu/dev/introgeo/studentresearch/examples/36302.html].

Greenlaw, S.A. and DeLoach, S. B. (2003) "Critical Thinking and Electronic Discussion.” Journal of Economic Education, 34(1), 36-52.

Greenlaw, S.A. (2006). Doing economics: a guide to understanding the carrying out economic research. Boston: Houghton Mifflin.

Greenlaw, S.A. (2010). "Teaching Principles Students How to Assess the State of the Economy," in Starting Point: Teaching and Learning in Economics, [internet:

http://serc.carleton.edu/econ/quantitative_writing/examples/31123.html]. 
Gregory, C. (2010). "Statistical Graphs: AIDS Cases and Deaths by Year and Historical Poverty in the US," in Starting Point: Teaching and Learning in Economics, [internet:

http://serc.carleton.edu/econ/quantitative_writing/examples/24068.html]

Hansen, W. L. (2001). Expected proficiencies for undergraduate economics majors. Journal of Economic Education, 32(3), 231-242.

Hansen, W.L. (2006, March). Proficiency-based economics course examinations. Paper presented at the meeting of the Midwest Economics Association, Chicago, IL.

Kinkead, J. (Ed.). (2003). Valuing and supporting undergraduate research [Special issue]. New Directions for Teaching and Learning, 93.

Kinkead, J. (2003). Learning through inquiry: An overview of undergraduate research. New Directions for Teaching and Learning, 93, 5-17.

Lilly, G. and Tiemann, T. (2008). "On the Struggle to Attain Universal Competence in a Complex Skill: The Case of a Senior Capstone Experience," Working Papers 2008-06, Elon University, Department of Economics [internet: http://ideas.repec.org/p/elo/wpaper/200806.html].

McGoldrick, K. (2007). Undergraduate research in economics. Handbook for Economics Lecturers.

McGoldrick, K. (2008a). "Writing Requirements and Economic Research Opportunities in the Undergraduate Curriculum: Results from a Survey of Departmental Practices.” Journal of Economic Education, 39, 3, 287-96.

McGoldrick, K. (2008b). "Doing economics: Enhancing skills through a process-oriented senior research course." Journal of Economic Education, 39, 4, 342-355.

McGoldrick, K. and Ziegert, A. (Eds.). (2002). Putting the invisible hand to work: concepts and models for service learning in economics. Ann Arbor: U Michigan Press.

Merkel, C. A. (2002). How to Mentor Undergraduate Researchers. Washington, D.C.: Council on Undergraduate Research.

Perry-Sizemore, E. (2010a). "The Effects of Condemned/Restored Homes on Surrounding Property Values: A Student/Faculty Collaborative Research and Service Learning Experience," in Starting Point: Teaching and Learning in Economics, [internet:

http://serc.carleton.edu/econ/studentresearch/examples/36203.html].

Perry-Sizemore, E. (2010b). "Using Census Data to Identify a Town's Housing Needs: A Student/Faculty Collaborative Research and Service Learning Experience," in Starting Point: 
Teaching and Learning in Economics, [internet:

http://serc.carleton.edu/econ/studentresearch/examples/36204.html].

Science Education Resource Center. "Starting Point: Teaching and Learning in Economics" (2010). [internet: http://serc.carleton.edu/econ/about.html].

Siegfried, J.J (2001) "Principles for a Successful Undergraduate Economics Honors Program." Journal of Economic Education, 32, 2, 169-77.

Siegfried, J.J., Bartlett, R., Hansen, W.L., Kelly, A., McClosky, \& Tietenberg, T. (1991). The status and prospects of the economics major. Journal of Economic Education, 22(3), 197-224.

Ziegert, A. \& McGoldrick, K. (2008). "When service is good for economics: Linking the classroom and community through service learning." International Review of Economics Education, 7(2), 39-56.

\section{Notes}

${ }^{1}$ Starting Point: Teaching and Learning Economics-A Source for Pedagogical Resources is supported by a grant from the National Science Foundation (DUE0817382, \$497,953, PIs: M. Maier, C. Manduca, K. McGoldrick, S. Simkins).

${ }^{2}$ The issues of student preparedness, structure (or project design) and faculty mentoring go hand in hand. Mentoring is best thought of as the necessary scaffolding provided by the faculty to meet the learning objectives. Since learning objectives differ significantly across undergraduate research experiences, so too does the kind and frequency of the mentoring. Some of these issues can be addressed through the structure of the experience. For example, rather than mentoring students in an introductory class about how to organize data in a spreadsheet, instructors can simply provide the ready-made data set for students use. In that way, faculty mentoring time can be used more efficiently by allowing it to focus on the primary learning objectives.

${ }^{3}$ However, McGoldrick (2008a) reports that only about 40 percent of economics departments require econometrics and 10 percent require a research methods course.

${ }^{4}$ This represents an important opportunity since, according to McGoldrick (2008a), the typical undergraduate economics major will write about three term papers in his or her program (a little more at liberal arts institutions).

${ }^{5}$ For example, some departments will allow students to do research projects in their second or third years. These are not capstone experiences, then, and they may not be collaborative research with a faculty. Chances are, they are simply opportunities for students to get some experience doing research early on, even though they do not have all the requisite content knowledge to complete a larger, capstone-like experience. This could be a particularly good option for 
departments that do not typically incorporate research projects into their applied field courses or for those that may not offer econometrics frequently.

${ }^{6}$ Obviously applied econometric analysis is not required for all research. Certainly theoretical and historical research is done at the undergraduate level as well. However, due to the nature of the modern-day undergraduate curriculum, most would agree that it is by far the most common type of research undertaken by undergraduates.

${ }^{7}$ Peer-reviewed publication need not be restricted to professional economics journals. There are an increasing number of undergraduate journals that publish economics papers (e.g., Issues in Political Economy, Undergraduate Economic review, etc.). For a listing of all undergraduate journals across the disciplines, see http://www.cur.org/ugjournal.html.

${ }^{8}$ This is especially true if the department has a research methods course that students take along the way. But even without such a course, students in such a setting can learn a great deal about research methods in the lab itself. This is the ultimate learning by doing.

${ }^{9}$ Such a course also provides faculty a natural place to stimulate interested students to joining the so-called "research teams" discussed previously.

${ }^{10}$ More information is available on the REU website: http://www.nsf.gov/funding/pgm_summ.jsp?pims_id=5517\&org=NSF. 